\title{
The Evolution of the Niobium Production in Brazil
}

\author{
Adilson Rangel Alves ${ }^{a, b}$, Aparecido dos Reis Coutinho ${ }^{a *}$ \\ ${ }^{a}$ Universidade Metodista de Piracicaba-UNIMEP, SP 306, Km 01, CEP 13450-971, \\ Santa Barbara d'Oeste, SP, Brasil \\ ${ }^{b}$ Centro Federal de Educação Tecnológica de Minas Gerais - CEFET-MG, Campus IV, \\ Av. Ministro Olavo Drummond, 25, CEP 38180-510, Araxá, MG, Brasil
}

Received: February 25, 2014; Revised: January 7, 2015

\begin{abstract}
Niobium $(\mathrm{Nb})$ was initially applied in the industry in 1933 to stabilize stainless steels against intergranular corrosion. Around 1970, niobium started to be used in many technological applications, especially in heat treatments at high temperatures, in the form of superalloys and, over the past four decades, $\mathrm{Nb}$ has been employed on an industrial scale. During recent years, applications of niobium have increased steadily in various segments such as: micro-alloyed steels, super alloys, thin films, medical implants, titanium and aluminum alloys, superconductors and copper alloys, electrolytic and ceramic capacitors. The worldwide demand for $\mathrm{Nb}$ grew at an annual rate of $10 \%$ between the years 2000-2010, were the sectors of energy, automotive and construction of the largest consumers FeNb. In 2000 the brazilian production was $35,458 \mathrm{t}$ of $\mathrm{Nb}$ and, in 2007, reached 82,000 $\mathrm{t}$ of concentrate $\mathrm{Nb}$. Brazil has the world's largest reserves of $\mathrm{Nb}(98.53 \%)$, which totaled 842.4 million t. So, in this paper is made a study on the evolution of the production of niobium in Brazil and its main industrial and technological applications.
\end{abstract}

Keywords: niobium, production, sustainability

\section{Historical Aspects}

The presence of niobium in nature is associated with pegmatite in the form of columbite, tantalite, or the alkali carbonatites mass, constituting the termed mineral pyrochlore ${ }^{1}$.

In the year 1801, the English chemist Charles Hatchett (1765-1847) discovered a new chemical element of atomic number 41. Initially it was called columbium, being the name given in honor of America, whence arose the mineral ${ }^{1-2}$. In 1802, the chemist Anders Gustaf Ekeberg (1767-1813) reported his findings to the French journal Annales de Chemie, the identification of a new element, which was named tantalum. In 1809, William Hyde Wollaston (1766-1828), responsible for the elements discovering rhodium and palladium announced that colombium and tantalum were identical ${ }^{1-3}$.

Years later, Heinrich Rose (1795-1864), noted the presence of two distinct elements in columbite, tantalum discovered by Ekeberg and others who called niobium, which corresponds in Greek mythology the daughter of tantalum, but it was actually the columbium discovered by Hatchett ${ }^{4}$.

In 1950, 149 years after the discovery of Hatchett, the International Union of Pure and Applied Chemistry (IUPAC) adopted Niobium as the official name. However, columbium name has been accepted for a long time by metallurgical and chemical industry in the U.S., so that name is still in use $\mathrm{e}^{1-5}$.

\subsection{The main properties of niobium}

Niobium belongs to the group of metals having a high melting point, is corrosion resistant, has good ductility at room temperature, consists of gray color, and acquires blue color when exposed to air for a long period ${ }^{6-7}$.
The niobium is resistant to corrosion due to the formation of an oxide film on its surface, when combined have multiple oxidation states, in which the +5 is the most common state. In ambient temperature conditions, does not react with hydrogen, air, water, or acids, except hydrofluoric acid and its mixture with nitric acid. On the other hand, under the effect of the temperature increase $\mathrm{Nb}$ reacts with most non-metallic and generates products that are non-stoichiometric and interstitial elements. Under these conditions, it is also resistant to attack by molten bases ${ }^{6-7}$.

$\mathrm{Nb}$ is characterized by having only one stable isotope, which has the crystalline structure in the form of bodycentered cubic (CCC). The physical and mechanical properties of the $\mathrm{Nb}$ are influenced by the purity of the metal, so even small quantities of interstitial impurities may promote degradation of the properties of the metal. The main impurities of $\mathrm{Nb}$ products in accordance with specifications of the American Society for Testing and Materials (ASTM), are oxygen, nitrogen, hydrogen, carbon, iron, molybdenum and tungsten ${ }^{7-8}$.

The physico-chemical properties of niobium are similar to tantalum, implying an occurrence together in nature, so that it becomes difficult their separation. One of the methods consists in the hydrometallurgy process known by use of methyl isobutyl ketone, under acidic conditions. This procedure allows the isolation of niobium pentoxide $\left(\mathrm{Nb}_{2} \mathrm{O}_{5}\right)$ which can be reduced from use of aluminum, known as aluminothermic process which generates niobium and aluminum oxide ${ }^{7-8}$.

The tables that follow show the main properties of niobium $^{9-11}$ : physic-chemical (Table 1) and mechanical (Table 2). 
Table 1. Physico-chemical properties of the niobium ${ }^{9-11}$.

\begin{tabular}{|c|c|}
\hline Physico-chemical Properties & Values \\
\hline Molecular weight & $92,906 \mathrm{~kg} / \mathrm{mol}$ \\
\hline Density & $8,570 \mathrm{Kg} / \mathrm{m}^{3}$ \\
\hline Atomic Number & $41 \mathrm{u}$ \\
\hline Crystalline structure & $\mathrm{CCC}$ \\
\hline Lattice parameter at $20^{\circ} \mathrm{C}$ & $3.294 \times 10^{-10} \mathrm{~m}$ \\
\hline Thermal shock to neutrals (barns) & 1.1 \\
\hline Thermal Neutron Cross Section & $0.65291 \times 10^{-10} \mathrm{~m}$ \\
\hline \multirow[t]{4}{*}{ X-ray Absorption Edge } & $0.65291 \times 10^{-10} \mathrm{~m}$ \\
\hline & $4.59111 \times 10^{-10} \mathrm{~m}$ \\
\hline & $5.02472 \times 10^{-10} \mathrm{~m}$ \\
\hline & $5.02472 \times 10^{-10} \mathrm{~m}$ \\
\hline \multirow[t]{2}{*}{ Crystal Ionic Radius } & $0.690 \times 10^{-10} \mathrm{~m}($ for Valence +5$)$ \\
\hline & $1.00 \times 10^{-10} \mathrm{~m}($ for Valence +1$)$ \\
\hline Electrochemical Equivalent & $450 \mathrm{~kg} / \mathrm{A} / \mathrm{h}$ \\
\hline Electronegativity & 1.6 (Pauling) \\
\hline Electrical Resistivity at $20^{\circ} \mathrm{C}$ & $13.2-14.8\left(10^{-6} \mathrm{ohm} . \mathrm{m}\right)$ \\
\hline Magnetic Susceptibility & $2.28 \times 10^{-6}$ \\
\hline Critical Magnetic Field Strength, Oersted & $1.59-1.67\left(10^{5} \mathrm{~A} / \mathrm{m}\right)$ \\
\hline Melting point & $2,195 \mathrm{~K}$ \\
\hline Boiling point & $4,854 \mathrm{~K}$ \\
\hline Heat of sublimation at $20^{\circ} \mathrm{C}$ & $7.18 \times 10^{5} \mathrm{~kJ} / \mathrm{kg}$-atom \\
\hline Heat of combustion at $20^{\circ} \mathrm{C}$ & $1.0 \times 10^{4} \mathrm{~kJ} / \mathrm{kg}$ \\
\hline Heat of Fusion & $2.9 \times 10^{5} \mathrm{~J} / \mathrm{kg}$ \\
\hline Heat of Vaporization & $7,704 \times 10^{6} \mathrm{~J} / \mathrm{kg}$ \\
\hline Specific Heat Capacity & $272 \mathrm{~J} / \mathrm{kg} . \mathrm{K}$ \\
\hline Heat of Formation & $\begin{array}{l}\underline{0.000} \mathrm{~kJ} / \mathrm{mol} \text { (cristal) } \\
\underline{725.9} \mathrm{~kJ} / \mathrm{mol} \text { (gas) }\end{array}$ \\
\hline CTE, linear & $\begin{array}{c}\left(20-100{ }^{\circ} \mathrm{C}\right) 7.10 \mu \mathrm{m} / \mathrm{m} . \mathrm{K} \\
\left(500{ }^{\circ} \mathrm{C}\right) 7.61 \mu \mathrm{m} / \mathrm{m} . \mathrm{K}\end{array}$ \\
\hline Thermal Conductivity & $\left(20^{\circ} \mathrm{C}\right) 52.3 \mathrm{~W} / \mathrm{m} . \mathrm{K}$ \\
\hline Superconducting critical temperature & $\begin{array}{c}\left(500^{\circ} \mathrm{C}\right) 63.2 \mathrm{~W} / \mathrm{m} . \mathrm{K} \\
9.23-9.27 \mathrm{~K}\end{array}$ \\
\hline
\end{tabular}

Table 2. Mechanical properties of the niobium ${ }^{9-11}$.

\begin{tabular}{lc}
\hline \multicolumn{1}{c}{ Mechanical Properties } & Values \\
\hline Hardness, Vickers & 80 \\
Tensile Strength, Ultimate & $300 \mathrm{MPa}$ \\
Tensile Strength, Yield & $207 \mathrm{MPa}$ \\
Elongation at Break & $30 \%$ \\
Modulus of Elasticity & $103 \mathrm{GPa}$ \\
Poissons Ratio & 0.38 \\
Shear Modulus & $37.5 \mathrm{GPa}$ \\
\hline
\end{tabular}

It is observed in Table 1 high values of melting point, exceeding many ferrous and nonferrous metals. Its high melting point permits its use as a component of various alloys $^{9-11}$.

With only 8.57 grams per cubic centimeter, the density of niobium is only about half that of tantalum, one of the lightest of refractory metals. Also, it has a higher strengthto-weight ratio compared to metals titanium, nickel, vanadium and zirconium. This is an important industrial, where weight is an important factor in the industrial use of the property $\mathrm{Nb}^{7-11}$.
The $\mathrm{Nb}$ presents high and higher values for the mechanical properties compared to ferrous metals in general, such as tensile strength and modulus of elasticity. Also, there is very low electrical resistivity of $\mathrm{Nb}$, compatible to other refractory metals. Moreover, its thermal conductivity increases directly with the increase in temperature, as well as most metals ${ }^{9-11}$.

\subsection{The main applications of niobium}

Niobium was first applied as a material in the industry in 1933 to stabilize stainless steels against intergranular corrosion. In early 1960s, researches showed that niobium contains microalloying properties that promote significant improvements in resistance of steels. Later, around 1970, Nb began to be used in several advanced applications, especially in heat at high temperatures, in the form of superalloys, and in the last four decades $\mathrm{Nb}$ has been employed in industrial scale ${ }^{12-14}$.

Most of the production of $\mathrm{Nb}$ is its processing as $\mathrm{FeNb}$, for direct use in the steel industry. Moreover, the $\mathrm{Nb}$ is employed in the design and production of special alloys, especially used in the manufacture of high-strength steels 
for the automotive, marine (offshore platforms, pipelines) and civil construction (bridges and buildings). In addition, $\mathrm{Nb}$ is used in the production of superalloys which are used at high temperatures, for example in the aerospace use that are present in the manufacture of turbine components ${ }^{6,12-17}$.

During recent years, applications of $\mathrm{Nb}$ have increased steadily in various segments such as: microalloyed steels, super alloys, thin films, medical implants, titanium and aluminum alloys, copper alloys and superconductors, ceramic capacitors and electrolytic, and others ${ }^{6,12-17}$.

In the construction industry $\mathrm{Nb}$ plays an important role in the development of more resistant steels, which can contribute to reduction of total project costs of infrastructure, even as they become increasingly complex. On the other hand, the demand of the construction industry will continue to be increasingly growing due to urbanization, population growth and replacement of infrastructure very old, so the need for lighter structures result in greater use of high quality steel containing $\mathrm{Nb}^{6,12-17}$.

In the automotive industry, increased employment of $\mathrm{Nb}$ led to a series of innovations in the manufacturing of parts requiring several types of steels, for example, steels with high strength low alloy, called HSLA. The manufacture of parts from use of HSLA steels help to reduce fuel consumption, reduce $\mathrm{CO}_{2}$ emissions and increase passenger safety. Therefore, in view the increased production of cars worldwide, the demand for $\mathrm{Nb}$ in the automotive industry is expected to grow significantly in the coming years ${ }^{6,12-17}$.

In the energy sector there forecasting strong growth in production and consumption natural gas $(\mathrm{NG})$ by the year 2035. For example, an increase around $20 \%$ in OECD countries (The Organisation for Economic Co-operation and Development) and up to $68 \%$ in non-OECD countries, according to information from the EIA (US Energy Information Administration). Consequently, the increase in production of $\mathrm{Nb}$ will be directly linked to the growth in demand for HSLA steel, depending on the need of transporting over long distances, high pressure, requiring steel tubes with increased mechanical strength and with this will increase the participation the niobium in energy production $^{12-17}$.

In the petroleum industry, the use of HSLA is higher, so that the increase in offshore drilling platforms entails the need for more stringent performance of the steels according to the harshest conditions in increasingly deep wells. Thus, in this segment the presence of niobium is essential in improve the properties of steels used in pipes, fittings and equipment for drilling in general ${ }^{12-17}$.

In the medical field, the use of niobium is growing and evolving, for example, is used in magnetic resonance imaging (MR), which is a diagnostic tool, whose use has increased significantly over the past three decades. In addition, another use is as an element of orthopedic implants by the addition of other bio compatibles metals ${ }^{18-19}$.

In the field of electronics and nanotechnology, niobium and tantalum in powders are used in industry as nanostructured materials, due to its characteristic of high purity, as small amounts of contaminants oxygen and metals low density ${ }^{18-19}$.

The trend in computing for the next decade is the possibility of the development of quantum computer. Quantum computing, such as atoms and molecules, does not follow the laws of physics and can process multiple data simultaneously, with unlimited capacity, and this is possible with the application of nanotechnology. So, the use of $\mathrm{Nb}$ contributes to this industrial segment. For example, in 2007, the Canadian D-Wave showed the Orion computer based on a silicon chip, which is formed by portion of niobium, surrounded by a coil. When the coil is electrically stimulated, it generates a magnetic field that causes changes in the state of $\mathrm{Nb}$ atoms. These state changes are captured and processed by the circuits and transformed into data. For all this to work, the quantum chip needs to be frozen to four milikelvins $(\mathrm{mK})$. This is done by means of a cooling system with liquid helium and becomes low temperature superconducting $\mathrm{Nb}^{12-20}$.

So, from the considerations and examples, Table 3 summarizes the main applications of niobium in various industry segments, and science and technology ${ }^{12-20}$.

In this scenario technological applications ranging from civil construction, shipbuilding, aerospace, energy, electronics, medical and other segments require a significant increase in niobium consumption, due to new projects that require lighter more resistant steels, lighter special alloys or byproducts of to meet increased demand of technical standards and innovative technology.

Table 3. Some types of products $\mathrm{Nb}$ and applications ${ }^{12-20}$.

\begin{tabular}{|c|c|c|}
\hline Niobium Species & Principal Properties & Applications \\
\hline $\mathrm{Nb}$ oxide & $\begin{array}{l}\text { High index of refraction } \\
\text { High dielectric constant } \\
\text { Increase light transmittance }\end{array}$ & $\begin{array}{l}\text { Camera lenses } \\
\text { Coating on glass for computer screens } \\
\text { Ceramic capacitors } \\
\text { Manufacture of lithium niobate for surface acoustic } \\
\text { wave filters }\end{array}$ \\
\hline $\mathrm{Nb}$ carbide & $\begin{array}{l}\text { High temperature deformation and controls grain } \\
\text { growth }\end{array}$ & Cutting tool compositions \\
\hline $\mathrm{Nb}$ powder & High dielectric constant, stability of oxide dielectric & $\mathrm{Nb}$ capacitors for electronic circuits \\
\hline $\mathrm{Nb}$ metal & Corrosion resistance & $\begin{array}{l}\text { Chemical processing } \\
\text { Equipment }\end{array}$ \\
\hline $\mathrm{FeNb}$ & $\begin{array}{l}\text { Weight reduction, increased strength and toughness } \\
\text { due to grain refining }\end{array}$ & $\begin{array}{l}\mathrm{Nb} \text { additive to high strength low alloy steel and } \\
\text { stainless steel }\end{array}$ \\
\hline $\begin{array}{l}\mathrm{Nb} \text { titanium and } \mathrm{Nb} \text { tin } \\
\text { alloys }\end{array}$ & $\begin{array}{l}\text { Very low electrical resistance of alloywire at low } \\
\text { temperatures }\end{array}$ & $\begin{array}{l}\text { Superconducting magnetic coils in magnetic } \\
\text { resonance imagery }\end{array}$ \\
\hline
\end{tabular}




\subsection{The demand for niobium}

As of 2010, the largest consumers of $\mathrm{Nb}$ are China, followed by North America and Europe. China is the strongest growth market in world of $\mathrm{Nb}$ consumption, accounting for $25 \%$ of total consumption, which reflects the size and importance of its steel industry. For example, China is the largest producer of stainless steel, and in the 1990s had an increase in their share in world production between $1-2 \%$ to $36.7 \%$ in $2010^{14-15,17,20}$.

The growth of steel production is not the only factor in sales increase of $\mathrm{Nb}$, so that another important factor that should be taken into account is the increase in the specific consumption of iron-niobium. For example, China showed an increase in specific consumption of FeNb of $11 \mathrm{~g} / \mathrm{t}$ in 2004 to $35 \mathrm{~g} / \mathrm{t}$ in 2008, while Brazil showed specific consumption of $100 \mathrm{~g} / \mathrm{t}$ of $\mathrm{FeNb}$ in $2008^{14-15,17,20}$.

The high rate of growth of the BRIC countries, GPD has directly resulted in increased demand for steel production. For example, world grew $5.1 \%$ in 2010 , which played an important role in the economies of the BRIC countries, which grew $8.8 \%$, which represents more than a third of world GPD growth. The forecast for 2020 is that the BRICs countries should contribute about $49.0 \%$ of overall growth, taking into account the growth of steel production and the direct increase in demand for $\mathrm{Nb}^{14-15,17,20}$.

Thus, in this scenario, the global demand for $\mathrm{Nb}$ grew at an annual rate of $10 \%$ between the years 2000-2010. Growth was driven by strong demand for steel, especially among the BRIC countries, which in 2010 produced around $1,4.10^{6} \mathrm{t}$, representing an increase of about $14 \%$, where the sectors of energy, automotive and construction industries showed largest consumers of $\mathrm{FeNb}^{14-15,17,20}$.
Figure 1 shows a simplified diagram of the main applications of $\mathrm{Nb}$ and its specific demand in the industrial and technological sector ${ }^{21-23}$.

The diagram shows the interrelationship of the various stages of production and consumption of $\mathrm{Nb}$ by means a direct connection between supply and demand of the product, which can divide the market for $\mathrm{Nb}$ in 3 phases: a) providing primary products; b) intermediate demand; c) the final demand. It is suggested that the market demand is divided into two types of products: alloy iron-niobium and niobium oxide alloy. The second type (niobium oxide) is related to the production of more sophisticated and high technology materials. The maximum production of one or another type of alloy is related to the technological factor, which is a guide for industrial production ${ }^{21-23}$.

The technological factor is directly linked to final demand, which determines the direction of the primary product. Final demand also demonstrates the level of technological development of the country, when the demand for more sophisticated products supplants the need for primary products, keeping in mind that the high-tech sectors such as medical, marine, aerospace, among others, seek to niobium in special alloys, high purity or superalloys ${ }^{21-23}$.

The growth in demand for raw materials called rare earths is in evidence, as well as its importance as a strategic material. According to $\mathrm{Moss}^{23}, 14$ metals that may be needed in significant amounts to the deployment of low-carbon steel, directed the productions of special alloys technologies were identified. For example, metals such as niobium, selenium, tin and vanadium, must show increase in their demand, requiring $1 \%$ or more of world supply per year in the period between 2020 and 2030. Niobium in turn has a significant demand, primarily for the use in steel used in oil pipelines, as well as in the aerospace and building industries ${ }^{21-23}$.

Structure of the niobium market
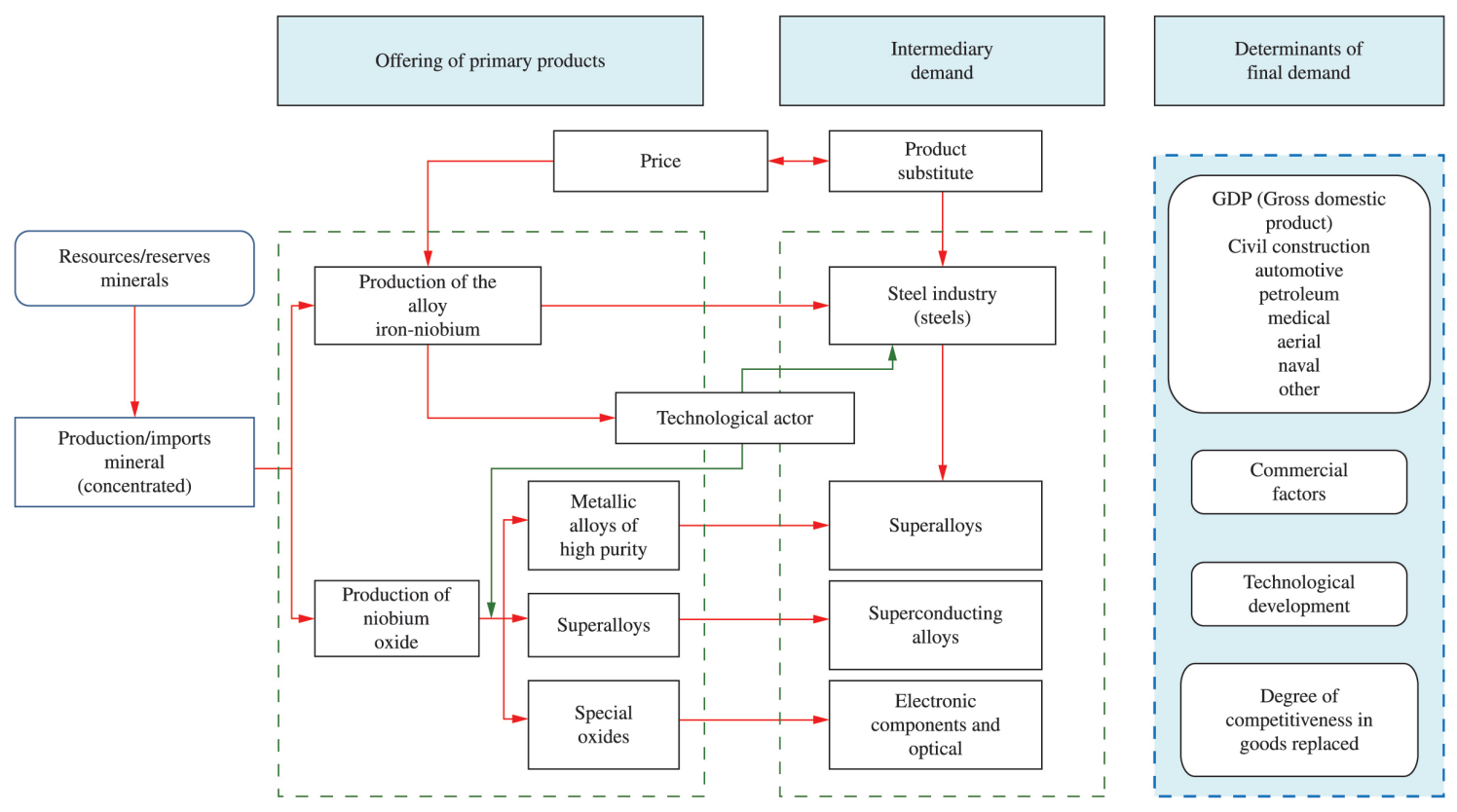

Figure 1. Simplified diagram of niobium the market ${ }^{3,6,21-23}$. 
Projections for niobium consumption was restricted to the main product, the alloy iron-niobium. The methodology used for the projections via explanatory model of consumption function, showed a demand of iron-niobium alloy in the order of $85,000 \mathrm{t}$ for 2010 and $188,000 \mathrm{t}$ in 2030, which correspond to 140 thousand $\mathrm{t}$ and 308,000 t respectively production of ore concentrated niobium, required to meet the anticipated demand for these years. The most significant increase niobium is yet to come, especially given the concern with sustainability. Iron-niobium can, for example, help produce lighter cars which consume less fuel $^{24-26}$.

\subsection{Production of niobium}

Brazil is one of the largest producers and exporters of minerals in the world. Table 4 shows the economic data exports of the main products of the mining sector, and the

Table 4. Main minerals exported ${ }^{24-26}$.

\begin{tabular}{lcc}
\hline \multicolumn{3}{c}{ Foreign trade of the mineral sector amounts in millions of US\$ } \\
\hline \multicolumn{1}{c}{ Main Products Exported } & $\mathbf{2 0 1 0}$ & $\mathbf{2 0 1 1}$ \\
\hline Export Mineral Primary Goods & 35,360 & 43,595 \\
Iron Ore & 28,912 & 35,745 \\
Gold (of bars) & 1,786 & 1,988 \\
Niobium (iron-niobium) & 1,557 & 2,034 \\
Copper & 1,238 & 1,806 \\
Silicon & 460 & 637 \\
Kaolin & 275 & 258 \\
Manganese Ore & 357 & 276 \\
Bauxite & 270 & 322 \\
Tin & 8 & 20 \\
Chumbo & 12 & 12 \\
Granite & 219 & 230 \\
Other & 268 & 268 \\
\hline
\end{tabular}

iron ore occupied the 1st place and that niobium reached gold, the list of brazilian exports ${ }^{24-26}$.

Figure 2 shows the evolution of brazilian export of $\mathrm{FeNb}$ between the years 2000 and 2011, were initially observed the increasing exports the order of $28,000 \mathrm{t}$ in 2000 to about $73,000 \mathrm{t}$ in 2008. In 2009 there was a sharp drop in export of $\mathrm{FeNb}$, to 45,000 t due to the global economic downturn, between 2008 to 2009. It is observed, however, the recovery in exports in the years 2010 and 2012, reaching a level of $70,000 \mathrm{t}$ again $^{24-26}$.

Brazil has the world's largest reserves of $\mathrm{Nb}(98.53 \%)$, followed by Canada (1.01\%) and Australia (0.46\%). Reservations measures brazilian niobium $\left(\mathrm{Nb}_{2} \mathrm{O}_{5}\right)$ totaled 842.4 million tons, with an average grade of $0.73 \% \mathrm{Nb}_{2} \mathrm{O}_{5}$ and are concentrated in the states of Minas Gerais (75.08\%), in Araxa and Tapira; Amazonas (21.34\%), in São Gabriel da Cachoeira and Presidente Figueiredo and Goiás (3.58\%), and in Catalão with an average grade of $0.73 \% \mathrm{Nb}_{2} \mathrm{O}_{5}{ }^{[24-26]}$.

In addition, Table 5 shows that Brazil stand out with $98.53 \%$ of the world $\mathrm{Nb}$ mineable reserves, and is the largest producer of the metal, representing approximately $97.2 \%$ of the global total. In this scenario, the State of Minas Gerais (MG) is the largest producer, with a share of $83.6 \%$, followed by the State of Goiás (GO) with $15.3 \%$ and the State of Amazonas (AM) with $1.1 \%{ }^{24-28}$.

Figure 3 shows the evolution of $\mathrm{FeNb}$ production in Brazil from 1965 to 2012. In the period 1965 to 1995 the production increased by about 5 times, and the 10-year period 1995-2005, the increase was about 4.5 times, the last 5 years, between the years 2005 - 2010, the increase in the production of niobium was 1.3 times $^{24-28}$.

In 2000, Brazilian production was $35,458 \mathrm{t}$ of $\mathrm{FeNb}$ and, in 2007, reached $82,000 \mathrm{t}$ of concentrate FeNb. This growth was due to the demand of FeNb due to the increase in steel production that accompanied economic growth in developing countries, especially China. In the Brazil two companies complete the cycle of the production of ore

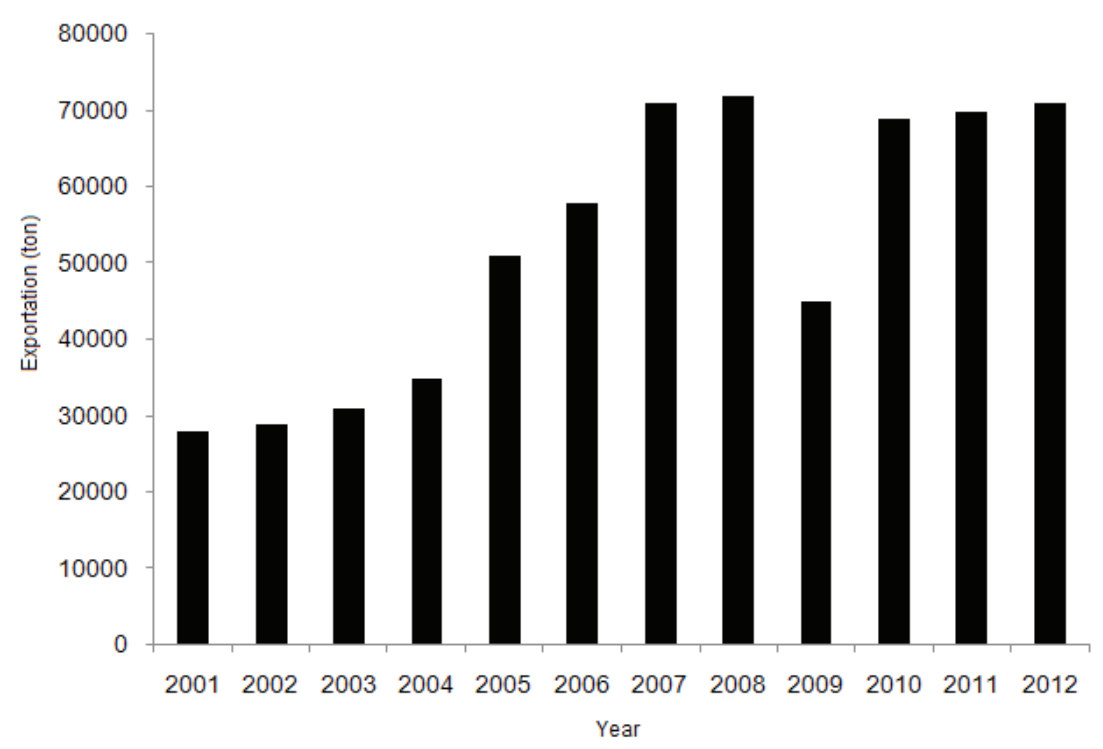

Figure 2. Evolution of the export of FeNb by Brazil ${ }^{24-26}$. 


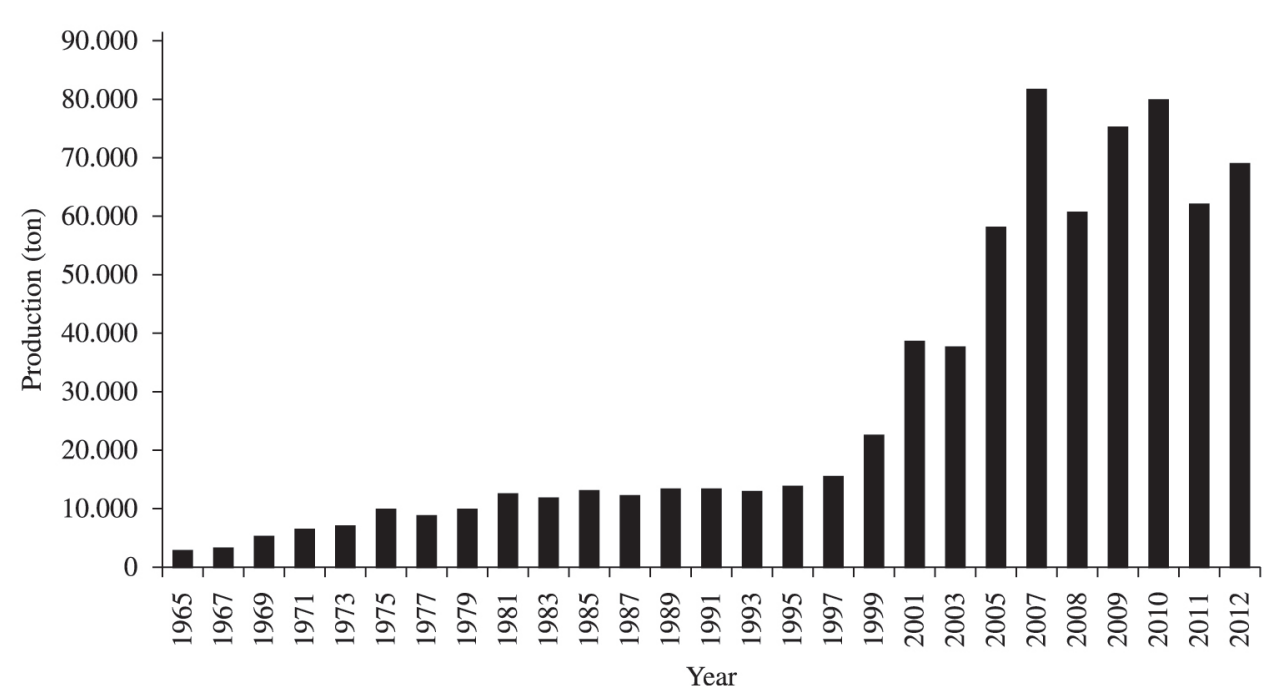

Figure 3. Historical of the production of niobium in Brazil ${ }^{24-26}$.

Table 5. Profile of the mineable reserves of niobium by countries $^{24-26}$.

\begin{tabular}{lc}
\hline \multicolumn{1}{c}{ Countries } & Reserves $\left(\mathbf{1 0}^{\mathbf{3}} \mathbf{t}\right)$ \\
\hline Brazil & 4,133 \\
Canadá & 61 \\
Others Countries & 21 \\
Total & 4,215 \\
\hline
\end{tabular}

and the niobium alloys, which are CBMM (Companhia Brasileira de Metalurgia e Mineração) in Araxá, Minas Gerais and Goiás Mining in Catalão $0^{27-28}$.

CBMM holds reserves estimated in 400 years with durability, predicts $60 \%$ growth in sales of FeNb until 2015 , with capacity to produce $90,000 \mathrm{t}$ of $\mathrm{FeNb}$ per year with goal of achieving production of $150000 \mathrm{t}$ in $2013^{27}$.

Another company, Anglo American Brazil, began operations in the city of Catalão (GO), in order to recover the $\mathrm{Nb}$ contained in the tailings and waste flotation of phosphate mining operations in the region. The material with an average grade of $0.5 \% \mathrm{Nb}_{2} \mathrm{O}_{5}$ feeds a concentration plant with capacity to produce $5,000 \mathrm{t} / \mathrm{y}$ of niobium concentrate with $48 \%$ of $\mathrm{Nb}_{2} \mathrm{O}_{5}{ }^{[28]}$.

Finely, Brazil accounts for almost the entire supply of the alloy iron-niobium metal and other compounds. Brazilian companies have a installed capacities for mining and metallurgy sufficient for the attendance current levels

\section{References}

1. Griffith WP and Morris PJT. Charles Hatchett FRS (17651847), chemist and discoverer of niobium. Notes \& Records of the Royal Society. 2003; 57(3):299-316. http://dx.doi. org/10.1098/rsnr.2003.0216.

2. Greenwood NN. Vanadium to dubnium: from confusion through clarity to complexity. Catalysis Today. 2003; 78(14):5-11. http://dx.doi.org/10.1016/S0920-5861(02)00318-8. of world demand, using modern technologies for mining, concentration and metallurgy and make significant investments in the expansion and modernization of production facilities metallurgy, as well as in research and development of new products made from niobium, encouraging diversification and increased use of niobium in the steel and metallurgical products ${ }^{24-28}$.

\section{Conclusions}

Brazil is the largest producer of almost all niobium consumption worldwide. In contrast, exports of ironniobium contribute to the surplus in the balance and this metal is now the third most important item on the agenda of mineral exports.

The scenario of increasing global demand for niobium in recent years at a rate of $10 \%$ per year puts the ore in a prominent position, since the greatest consumption occurred from 2004, primarily driven by increased production and consumption of steel in the world.

New applications for the ore are welcome and every effort should be made. However, to further develop technology, it becomes necessary to develop new materials and thereby increase the demand for the metal.

Thus, strategies that promote the Brazil's natural heritage could be further encouraged by the government to do more to harness the national well that the historical market insertion and openness to foreign capital, can give the real importance that your product has to the world market.

3. Silva PP and Guerra W. Platina. Química Nova na Escola. 2010; 32:128-129.

4. Steed J. Chemistry in its element: niobium. London: Royal Society of Chemistry; 2013. Available from: <http://www. rsc.org/chemistryworld/podcast/interactive_periodic_table transcripts/niobium.asp $>$.

5. Sousa RMF, Fernandes LE and Guerra W. Nióbio. Química Nova na Escola. 2013; 35:68-69. 
6. Grill R and Gnadenberger A. Niobium as mint metal: production: properties: processing. International Journal of Refractory Metals \& Hard Materials. 2006; 24(4):275-282. http://dx.doi.org/10.1016/j.jirmhm.2005.10.008.

7. Grill R. Niobium for coins. TIC Tantalum: Niobium. International Study Center-Bulletin. 2007; 129:6-8.

8. Ayanda OS and Adekola FA. A review of niobium-tantalum separation in Hydrometallurgy. Journal of Minerals \& Materials Characterization \& Engineering. 2011; 10:245-256.

9. ASM International. Properties and selection of the metals. 8th ed. Ohio; 1961. ASM Handbook 1.

10. ASM International. Properties and selection: nonferrous alloys and special-purpose materials. 10th ed. Ohio; 1990. ASM Handbook 2.

11. Kepert DL. The early transition metals. London: Academic Press; 1972. 142 p.

12. Rowe CED. Tantalum and Niobium in chemical applications. Tantalum-Niobium International Study Center Bulletin. 1999; 97:2-5.

13. Graham RA, Sutherlin RC and Wah C. Niobium and Niobium alloys in corrosive applications. In: Niobium Science and Technology; 2001. Florida: TMS; 2001. p. 337-355.

14. Oliveira M, Jansto S, Mohrbacher H, Patel J and Stuart M. 30 Years of Niobium steel development in China. 2013. Available from: <http://www.metal.citic.com/iwcm/UserFiles/img/ zlk/03_30zn/d7.pdf $>$.

15. Aggarwal G, Park SJ and Smid I. Development of niobium powder injection molding. Part I: feedstock and injection molding. International Journal of Refractory Metals \& Hard Materials. 2006; 24(3):253-262. http://dx.doi.org/10.1016/j. ijrmhm.2005.06.003.

16. Tither G. Progress in Niobium markets and technology 19812001. In: Proceedings of the International Symposium Niobium; 2001. Orlando, Florida. Available from: <http://www.cbmm. com.br/portug/sources/techlib/science_techno/table_content/ images/pdfs/oppening.pdf>.

17. IAMGOLD. Niobium 101. 2012. Available from: <www. iamgold.com/English/Operations/Operating-Mines/NiobecNiobium-Mine/Niobium-101/default.aspx>.

18. Alberich Bayarri A, Martí Bonmatí L, Lafuente J, Guibelalde del Castillo E, Escuela Superior de Resonancia Magnética
Clínica and Asociación para el Desarrollo y la Investigación en Resonancia Magnética. Utilización segura de la resonancia magnética. Recomendaciones prácticas para el personal que trabaja con resonancia magnética. Radiología. 2013; 55(2):99-106. http://dx.doi.org/10.1016/j.rx.2012.10.005. PMid:23332580

19. Grabis J, Munter R, Blagoveshchenskiy Y, Gorkunov V and Yamshchikov L. Plasmochemical Process for the Production of Niobium and Tantalum Nanopowders. Proceedings of the Estonian Academy of Sciences. 2012; 61(2):137-145. http:// dx.doi.org/10.3176/proc.2012.2.06.

20. Oliveira M, Jansto S, Mohrbacher H, Patel J and Stuart M. China technology development Nb-steel. In: 30th Anniversary International Symposium; 2013. Available from: $<$ http://www. metal.citic.com/iwcm/UserFiles/img/zlk/03_30zn/d7.pdf>.

21. Herbst L. A solution and solid state study of niobium complexes. [Dissertation of Magister Scientiae]. South Africa: Faculty of Natural and Agricultural Sciences, University of the Free State; 2012.

22. Silva LGO. Nióbio: mercado nacional e internacional, modelo de previsão do consumo de ferro-nióbio. [Dissertação]. Campinas: UNICAMP; 1994. 117 p.

23. Moss RL, Tzimas E, Kara H, Willis P and Kooroshy J. The potential risks from metals bottlenecks to the deployment of strategic energy technologies. Energy Policy. 2013; 55:556564. http://dx.doi.org/10.1016/j.enpol.2012.12.053.

24. Brasil. Ministério de Minas e Energia. Departamento Nacional de Produção Mineral - DNPM. Sumário Mineral. Brasília; 2012. 136 p.

25. Departamento Nacional de Produção Mineral - DNPM. Brasília; 2009. Available from: <https://sistemas.dnpm.gov. br/publicacao/mostra_imagem.asp?IDBancoArquivoArqui vo $=5481>$.

26. Instituto Brasileiro de Mineração - IBRAM. Informações e análises da economia mineral brasileira. 7. ed. Belo Horizonte; 2012.

27. Companhia Brasileira de Metalurgia e Mineração - CBMM. 2013. Available from: <http://www.cbmm.com.br/br/p/108/ home.aspx>.

28. Anglo American. Goiás: Mineração Catalão. Available from: $<$ http://www.angloamerican.com.br>. 